\title{
Pseudomonas pachastrellae sp. nov., isolated from a marine sponge
}

Correspondence Lyudmila A. Romanenko Iro@piboc.dvo.ru

\author{
Lyudmila A. Romanenko, ${ }^{1}$ Masataka Uchino, ${ }^{2}$ Enevold Falsen, ${ }^{3}$ \\ Galina M. Frolova, ${ }^{1}$ Natalia V. Zhukova ${ }^{4}$ and Valery V. Mikhailov ${ }^{1}$ \\ ${ }^{1}$ Pacific Institute of Bioorganic Chemistry, Far-Eastern Branch, Russian Academy of Sciences, \\ 690022 Vladivostok, Prospect 100 Let Vladivostoku, 159, Russia \\ ${ }^{2}$ Laboratory of Food Science and Technology, Department of Applied Biology and Chemistry, \\ Tokyo University of Agriculture, 1-1-1 Sakuragaoka, Setagaya-ku, Tokyo 156-8502, Japan \\ ${ }^{3}$ CCUG Culture Collection, Department of Clinical Bacteriology, University of Göteborg, \\ Guldhedsgatan 10, S-413 46 Göteborg, Sweden
}

${ }^{4}$ Institute of Marine Biology, Far-Eastern Branch, Russian Academy of Sciences, 690041 , Vladivostok, Russia

Two Gram-negative, non-fermentative, non-denitrifying, non-pigmented, rod-shaped bacteria

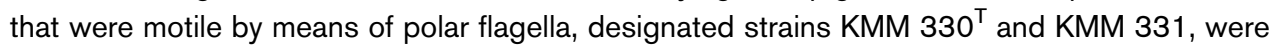
isolated from a deep-sea sponge specimen and subjected to a polyphasic taxonomic study. The new isolates exhibited 16S rRNA gene sequence similarity of $99.9 \%$, and their mean level of DNA-DNA relatedness was $82 \%$. Phylogenetic analysis based on their $16 \mathrm{~S}$ rRNA gene sequences placed the strains within the genus Pseudomonas as an independent deep clade. Strain KMM $330^{\top}$ shared highest sequence similarity (96.3\%) with each of Pseudomonas fulva NRIC $0180^{\top}$, Pseudomonas parafulva AJ $2129^{\top}$ and Pseudomonas luteola IAM 13000'; sequence similarity to other recognized species of the genus Pseudomonas was below $95 \cdot 7 \%$. The marine sponge isolates $\mathrm{KMM} 330^{\top}$ and $\mathrm{KMM} 331$ could be distinguished from the other recognized Pseudomonas species based on a unique combination of their phenotypic characteristics, including growth in 8 or $10 \% \mathrm{NaCl}$, the absence of pigments, the inability to denitrify and lack of carbohydrate utilization. On the basis of phylogenetic analysis, physiological and biochemical characterization, strains $\mathrm{KMM} 330^{\top}$ and $\mathrm{KMM} 331$ should be classified as a novel species of the genus Pseudomonas, for which the name Pseudomonas pachastrellae sp. nov.

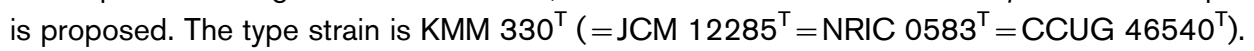

Pseudomonads are well-known and widespread microorganisms, which have been isolated from a variety of natural sources, soil, plants, mineral waters and clinical specimens, and they are characterized by a high level of metabolic diversity (Rosselló et al., 1991; Moore et al., 1996). The vast majority of species formerly assigned to Pseudomonas and recovered from marine sources are now classified within other genera (Kersters et al., 1996; Brown et al.,

Published online ahead of print on 18 November 2004 as DOI 10.1099/ijs.0.63176-0.

Abbreviations: DPG, diphosphatidylglycerol; PC, phosphatidylcholine; $\mathrm{PE}$, phosphatidylethanolamine; $\mathrm{PG}$, phosphatidylglycerol.

The GenBank/EMBL/DDBJ accession numbers for the 16S rRNA gene sequences of $\mathrm{KMM} 330^{\top}$ and $\mathrm{KMM} 331$ are $\mathrm{AB} 125366$ and AB125367, respectively.

Images of cell morphology, a thin-layer chromatogram of polar lipids and a maximum-likelihood tree are available as supplementary figures in IJSEM Online.
2001; Yoon et al., 2003). Relatively few species originating from marine environments are included within Pseudomonas (sensu stricto), including Pseudomonas stutzeri (later synonym Pseudomonas perfectomarina) (Baumann et al., 1983; Rosselló-Mora et al., 1993), Pseudomonas alcaligenes, Pseudomonas pseudoalcaligenes (Palleroni, 1984) and Pseudomonas alcaliphila (Yumoto et al., 2001) from sea waters, and some strains of Pseudomonas balearica (Bennasar et al., 1996) have been recovered from marine sediments.

In the present study two Pseudomonas-like bacteria isolated from a deep-sea sponge specimen were investigated by using a polyphasic taxonomic approach. The new strains KMM $330^{\mathrm{T}}$ and KMM 331 appeared to have homogeneous phenotypic characteristics and to be closely related based on phylogenetic and DNA-DNA hybridization experiments, but clearly distinct from all recognized Pseudomonas species. Based on the phenotypic and molecular data obtained, a novel species, Pseudomonas pachastrellae sp. nov., is described. 
Two strains, KMM $330^{\mathrm{T}}$ and KMM 331, were isolated from a sponge specimen of Pachastrella sp., collected in 1991 from the Philippine Sea at a water depth of $750 \mathrm{~m}$. A small amount of internal tissue of the sponge was homogenized and aliquots of the diluted homogenates were spread on agar plates of sea water medium (SWM), containing: $5.0 \mathrm{~g}$ peptone $\mathrm{l}^{-1}, 2 \cdot 5 \mathrm{~g}$ yeast extract $\mathrm{l}^{-1}, 1 \cdot 0 \mathrm{~g}$ glucose $\mathrm{l}^{-1}, 0 \cdot 2 \mathrm{~g}$ $\mathrm{K}_{2} \mathrm{HPO}_{4} \mathrm{l}^{-1}, 0.05 \mathrm{~g} \mathrm{MgSO}_{4} \mathrm{l}^{-1}$ and $15.0 \mathrm{~g}_{\text {agar } \mathrm{l}^{-1} \text { in }}$ $750 \mathrm{ml}$ sea water $/ 250 \mathrm{ml}$ distilled water. The inoculated plates were incubated for 14 days at $28^{\circ} \mathrm{C}$. Each colony was picked, re-streaked on the agar nutrient media and tested. The bacteria were grown aerobically on marine 2216 agar (MA) or marine broth (MB; Difco) and trypticase soy agar (TSA) at $25-28^{\circ} \mathrm{C}$. They were also stored at $-80^{\circ} \mathrm{C}$ in the liquid medium supplemented with $30 \%(\mathrm{v} / \mathrm{v})$ glycerol. Strains KMM $330^{\mathrm{T}}$ and KMM 331 have been deposited in the Collection of Marine Micro-organisms (KMM) of the Pacific Institute of Bioorganic Chemistry, Vladivostok, Russia. The following Pseudomonas type strains, P. stutzeri CIP $103022^{\mathrm{T}}, P$. alcaligenes CIP $101034^{\mathrm{T}}, P$. pseudoalcaligenes CIP $66.14^{\mathrm{T}}$ and Pseudomonas mendocina CIP $75.21^{\mathrm{T}}$, were kindly provided by the Collection de l'Institut Pasteur, Paris, France. Motility was observed by the hanging drop method. Cell morphology was examined by transmission electron microscopy from exponential phase cells grown in MB. Cells were negatively stained with potassium phosphotungstate $(1 \%, \mathrm{w} / \mathrm{v} ; \mathrm{pH} 7 \cdot 0)$. Production of pyocyanin and formation of fluorescent pigments were tested on King A and King B medium, respectively (King et al., 1954). The Gram-reaction, oxidase and catalase reactions and production of amylase, caseinase, DNase, gelatinase and lipase (Tween 80) were determined according to the methods described by Smibert \& Krieg (1994). Acid production from carbohydrates was examined by using the medium of Leifson (1963) for marine bacteria. The API 20NE, API $32 \mathrm{GN}$ and API ZYM systems (bioMérieux) were additionally used to test biochemical properties and these tests were performed according to the manufacturer's instructions. The temperature range for growth was determined on TSA and MA at $4,7,12,28,37,41,42$ and $43^{\circ} \mathrm{C}$. The $\mathrm{pH}$ range for growth $(5 \cdot 0-10 \cdot 0)$ was tested using trypticase soy broth (TSB) and MB. Growth requirement for sodium ions and salt tolerance were examined on SWM prepared on a distilled water base supplemented with an appropriate amount of $\mathrm{NaCl}$ ranging from 0 to $15 \%(\mathrm{w} / \mathrm{v})$. DNA was isolated by the procedure of Marmur (1961). DNA base composition was determined as described by Marmur \& Doty (1962) and Owen et al. (1969). The level of DNADNA relatedness between strains KMM $330^{\mathrm{T}}$ and KMM 331 was measured spectrophotometrically by using the initial renaturation rate method of De Ley et al. (1970). The photobiotin-labelled DNA probe microplate method of Ezaki et al. (1989) was used to determine genetic relatedness of strain $\mathrm{KMM} 330^{\mathrm{T}}$ and selected type strains of Pseudomonas species, including Pseudomonas aeruginosa, Pseudomonas fluorescens, Pseudomonas fulva, Pseudomonas luteola, Pseudomonas parafulva, Pseudomonas putida, Pseudomonas straminea and P. stutzeri. Bacteria were grown on TSA at $28^{\circ} \mathrm{C}$ for $48 \mathrm{~h}$ and whole-cell fatty acids were determined in accordance with the procedure described by Svetashev et al. (1995). Cellular quinones were determined by HPLC (LC-6A; Shimadzu) using a Cosmosil 5C18 column $(4 \cdot 6 \times$ $150 \mathrm{~mm})$, with acetonitril/2-propanol $(50: 50, \mathrm{v} / \mathrm{v})$ as the eluant $\left(0.5 \mathrm{ml} \mathrm{min}^{-1}\right)$, at a temperature $40{ }^{\circ} \mathrm{C}$ and with an SPD-2AM (270 nm) UV detector. Polar lipids were examined as described by Vaskovsky \& Terekhova (1979). 16S rRNA gene sequences of the strains tested were determined and compared as described by Shida et al. (1997). The sequences obtained were compared with 16S rRNA gene sequences retrieved from the EMBL/GenBank/DDBJ databases by using the FASTA program (Pearson \& Lipman, 1988). Distances were calculated according to the method of Jukes \& Cantor (1969). Phylogenetic trees were constructed by the neighbour-joining method of Saitou \& Nei (1987) with the CLUSTAL X program (version 1.8; Thompson et al., 1997) and by the maximum-likelihood method using the BIOEDIT program (Hall, 1999).

The marine isolates KMM $330^{\mathrm{T}}$ and KMM 331 were Gramnegative, non-pigmented, rod-shaped encapsulated bacteria that were motile by means of a single polar flagellum (see Supplementary Fig. A in IJSEM Online). Physiological, biochemical and chemotaxonomic characteristics of strains KMM $330^{\mathrm{T}}$ and KMM 331 are given in Table 1 and under the species description below.

The polar lipid compositions of strains $\mathrm{KMM} 330^{\mathrm{T}}$ and KMM 331 were identical (see Supplementary Fig. B in IJSEM Online) and consistent in their major components with those previously published for other Pseudomonas species. The presence of phosphatidylethanolamine (PE) as the predominant phospholipid, with smaller amounts of phosphatidylglycerol (PG) and diphosphatidylglycerol (DPG), in the fluorescent pseudomonads and their close relatives has been previously reported by Wilkinson (1988). Polar lipids consisting of PE, PG, DPG, phosphatidylcholine (PC), unknown phospholipids, unknown aminophospholipids and unknown polar lipids were detected in Pseudomonas oleovorans and Pseudomonas psychrotolerans by Hauser et al. (2004). The polar lipids of strains KMM $330^{\mathrm{T}}$ and KMM 331 did not include PC or aminophospholipid components.

Strains KMM $330^{\mathrm{T}}$ and KMM 331 contained isoprenoid quinone $\mathrm{Q}_{9}$ and $\mathrm{C}_{16: 0}, \mathrm{C}_{16: 1} \omega 9 \mathrm{c}$ and $\mathrm{C}_{18: 1}$ as the dominant fatty acids, in agreement with data previously reported for Pseudomonas species (Oyaizu \& Komagata, 1983) and for P. stutzeri strains (Rainey et al., 1994), P. fulva, P. parafulva and related species (Uchino et al., 2001) and P. alcaliphila (Yumoto et al., 2001).

The DNA G + C contents of the new isolates KMM $330^{\mathrm{T}}$ and KMM 331 were $61 \cdot 1$ and $61.5 \mathrm{~mol} \%$, respectively, which is within the range reported for most Pseudomonas species (Palleroni, 1984).

On the basis of their quinone, polar lipid and fatty acid 


\begin{tabular}{|c|c|c|c|c|c|c|c|c|c|c|c|c|c|c|}
\hline $\begin{array}{l}\text { Strains/species: } 1, P \text {. pacho } \\
\text { parafulva; } 9, \text { P. stutzeri; } 1 \\
\text { et al. }(2000,2001) \text {, Anzai }\end{array}$ & $\begin{array}{l}\text { trellae sp. no } \\
\text { P. balearica; } \\
\text { t al. (1997), }\end{array}$ & $\begin{array}{l}\text { strain } \\
11, P \text {. } \\
\text { ennasa }\end{array}$ & $\begin{array}{l}\mathrm{KMM} \\
\text { endocin } \\
\text { et al. }(\end{array}$ & $\begin{array}{l}30^{\mathrm{T}} \text { and } \mathrm{KN} \\
; 12, P \text {. alco } \\
996) \text { and } \mathrm{Yl}\end{array}$ & $\begin{array}{l}331 ; 2, P \text {. } \\
\text { enes; } 13, P \text {. } \\
\text { oto et al. }\end{array}$ & eudoa & $\begin{array}{l}\text { a; } 3 \text {, P. fluor } \\
\text { aligenes; } 14 \text {, } \\
\text { Positive; - }\end{array}$ & $\begin{array}{l}\text { scens bi } \\
\text {. alcali } \\
\text { negativ }\end{array}$ & $\begin{array}{l}\text { var } 1 ; 4, P . p \\
\text { hila. Data ar } \\
\text { d, different }\end{array}$ & $\begin{array}{l}\text { utida biovars } \\
\text { from the p } \\
\text { eaction betv }\end{array}$ & $\begin{array}{l}\text { 5, P. strami } \\
\text { sent study a } \\
\text { en strains; }\end{array}$ & $\begin{array}{l}\text { ea; } 6, P \\
d \text { from } \\
\text {, not }\end{array}$ & $\begin{array}{l}\text { teola; } 7 \text {, } \\
\text { lleroni } \\
\text { rmined. }\end{array}$ & $\begin{array}{l}\text { fulva; } 8, P \text {. } \\
\text { 984), Uchino }\end{array}$ \\
\hline Characteristic & 1 & 2 & 3 & 4 & 5 & 6 & 7 & 8 & 9 & 10 & 11 & 12 & 13 & 14 \\
\hline \multicolumn{15}{|l|}{ Production of: } \\
\hline $\begin{array}{l}\text { Yellow-orange water- } \\
\text { insoluble pigments }\end{array}$ & - & - & - & - & + & + & + & + & $\mathrm{d}$ & - & + & $\mathrm{d}$ & - & - \\
\hline $\begin{array}{l}\text { Fluorescent pigments } \\
\text { on King B medium }\end{array}$ & - & $\mathrm{d}$ & + & + & + & - & - & - & - & - & - & - & - & - \\
\hline Pyocyanin & - & + & - & - & - & - & - & - & - & - & - & - & - & - \\
\hline Number of flagella & 1 & 1 & $>1$ & $>1$ & 1 & 1 & 1 & 1 & $1^{*}$ & 1 & $1^{*}$ & 1 & 1 & 1 \\
\hline Denitrification & - & + & - & - & - & - & - & - & + & + & + & + & $\mathrm{d}$ & - \\
\hline Arginine dihydrolase & - & + & + & + & - & + & + & + & - & - & + & + & $\mathrm{d}$ & + \\
\hline \multicolumn{15}{|l|}{ Growth at: } \\
\hline $4^{\circ} \mathrm{C}$ & - & - & + & $\mathrm{d}$ & + & - & + & $\mathrm{d}$ & - & ND & - & - & - & + \\
\hline $41{ }^{\circ} \mathrm{C}$ & + & + & - & - & - & + & - & - & + & + & + & + & + & - \\
\hline Tolerance of $8 \% \mathrm{NaCl}$ & + & - & - & - & - & - & - & - & - & + & - & - & - & - \\
\hline \multicolumn{15}{|l|}{ Hydrolysis of: } \\
\hline Gelatin & - & + & + & - & - & + & - & ND & - & - & - & $\mathrm{d}$ & $\mathrm{d}$ & + \\
\hline Starch & - & - & - & - & - & - & - & - & + & + & - & - & - & - \\
\hline Tween 80 & + & $\mathrm{d}$ & $\mathrm{d}$ & $\mathrm{d}$ & - & + & + & - & + & ND & + & d & - & + \\
\hline \multicolumn{15}{|l|}{ Utilization of: } \\
\hline D-Glucose & - & + & + & + & + & + & + & + & + & ND & + & - & - & + \\
\hline Maltose & - & - & - & - & - & + & - & - & + & + & - & - & - & - \\
\hline Xylose & - & - & + & $\mathrm{d}$ & + & + & - & - & - & + & - & - & - & - \\
\hline Fructose & - & + & + & + & + & + & + & + & $\mathrm{d}$ & ND & $\mathrm{d}$ & - & + & + \\
\hline D-Mannose & - & - & + & $\mathrm{d}$ & + & + & + & + & - & $\mathrm{ND}$ & - & - & - & - \\
\hline Sucrose & - & - & + & $\mathrm{d}$ & - & - & - & - & - & ND & - & - & - & - \\
\hline Trehalose & - & - & + & - & - & + & - & - & - & ND & - & - & - & - \\
\hline Glycerol & - & + & + & + & - & + & + & + & + & ND & $\mathrm{d}$ & - & $\mathrm{d}$ & + \\
\hline D-Mannitol & - & + & + & $\mathrm{d}$ & + & + & - & - & d & - & - & - & - & + \\
\hline Gluconate & - & + & + & + & + & + & + & + & $\mathrm{d}$ & ND & + & - & $\mathrm{d}$ & ND \\
\hline Malate & - & + & + & + & - & + & + & + & + & + & - & + & + & + \\
\hline L-Valine & - & $\mathrm{d}$ & + & + & - & - & + & + & + & ND & + & - & - & - \\
\hline L-Lysine & - & + & + & $\mathrm{d}$ & - & + & + & + & - & ND & - & - & - & $\mathrm{ND}$ \\
\hline L-Tyrosine & + & + & + & + & - & + & $\mathrm{d}$ & + & $\mathrm{d}$ & $\mathrm{ND}$ & + & $\mathrm{d}$ & $\mathrm{d}$ & $\mathrm{ND}$ \\
\hline $\begin{array}{l}\text { DNA G +C content } \\
(\mathrm{mol} \%)\end{array}$ & $61 \cdot 1-61 \cdot 5$ & $67 \cdot 2$ & $60 \cdot 5$ & $60 \cdot 7-62 \cdot 5$ & $62 \cdot 5-63 \cdot 7$ & $54 \cdot 8$ & $60 \cdot 0-61 \cdot 5$ & $60 \cdot 0$ & $60 \cdot 6-66 \cdot 3$ & $64 \cdot 1-64 \cdot 4$ & $62 \cdot 8-64 \cdot 3$ & $64-68$ & $62-64$ & $62 \cdot 3-63 \cdot 2$ \\
\hline
\end{tabular}




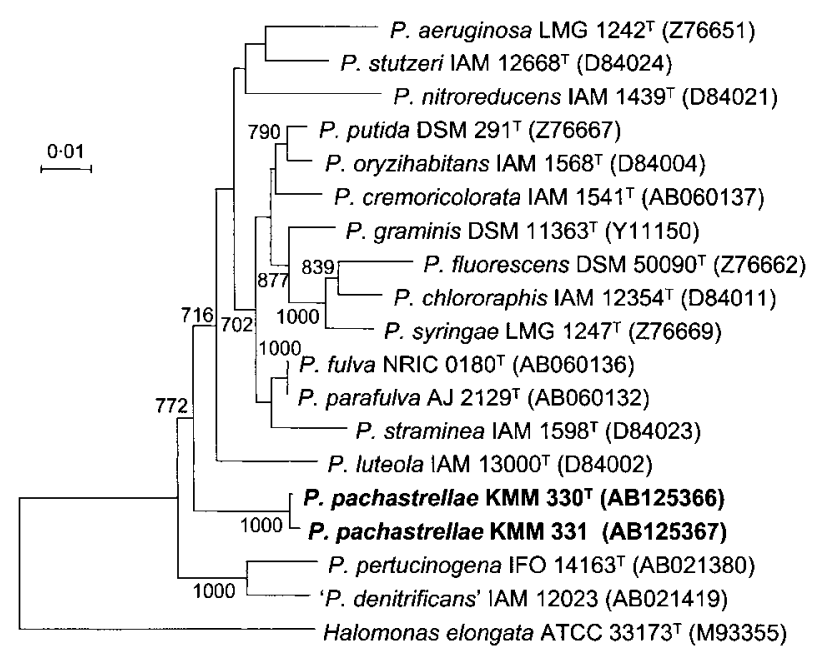

Fig. 1. Phylogenetic relationships of isolates $\mathrm{KMM} 330^{\top}$ and KMM 331 and some related Pseudomonas species on the basis of $16 \mathrm{~S}$ rRNA gene sequence analysis. The branching pattern was generated by the neighbour-joining method. Numbers indicate bootstrap values greater than 700 . Bar, 0.01 $K_{\text {nuc }}$ units. A tree generated by the maximum-likelihood method is available as Supplementary Fig. C in IJSEM Online.

compositions, DNA base composition, cell morphology and motility and physiological characteristics, the isolates can be considered to be members of the genus Pseudomonas.

Strains KMM $330^{\mathrm{T}}$ and KMM 331 had 16S rRNA gene sequence similarity of $99 \cdot 9 \%$. P. fulva NRIC $0180^{\mathrm{T}}, P$. parafulva AJ $2129^{\mathrm{T}}$ and $P$. luteola IAM $13000^{\mathrm{T}}$ were the closest phylogenetic relatives (each 96.3\% 16S rRNA gene sequence similarity). Strains KMM $330^{\mathrm{T}}$ and KMM 331 shared $95 \cdot 7 \%$ 16S rRNA gene sequence similarity with $P$. straminea IAM $1598^{\mathrm{T}}$ and $95.3 \%$ similarity with 'Pseudomonas denitrificans' IAM 12023. These values fall within the range of $16 \mathrm{~S}$ rRNA gene sequence similarities (93.7-99.9\%) reported for species of the genus Pseudomonas (Moore et al., 1996; Anzai et al., 2000). 16S rRNA gene sequence similarity values of below $97 \%$ have been stated by Stackebrandt \& Goebel (1994) to be an accepted criterion for differentiation of bacteria at the species level. Relatively low 16S rRNA gene sequence similarities (96.3\% to $P$. luteola IAM $13000^{\mathrm{T}}$, P. fulva NRIC $0180^{\mathrm{T}}$ and $P$. parafulva AJ $2129^{\mathrm{T}}, 95 \cdot 7 \%$ to $P$. straminea IAM $1598^{\mathrm{T}}$ and values below this to other Pseudomonas species) clearly demonstrated that the new isolates could be regarded as members of an independent species. Phylogenetic analysis based on the $16 \mathrm{~S}$ rRNA gene sequences revealed a clear affiliation of the new isolates to members of the genus Pseudomonas. Different algorithms placed strains KMM $330^{\mathrm{T}}$ and KMM 331 as a separate clade adjacent to $P$. luteola IAM $13000^{\mathrm{T}}$ and to the Pseudomonas pertucinogena IFO $14163^{\mathrm{T}}$ and 'P. denitrificans' IAM 12023 cluster (Fig. 1; see also Supplementary Fig. C in IJSEM Online). The species relatedness of the $P$. pertucinogena cluster and
P. luteola among Pseudomonas species found in our analyses has been observed in other phylogenetic studies (Anzai et al., 1997, 2000; Peix et al., 2003).

Strains KMM $330^{\mathrm{T}}$ and KMM 331 possessed a high level of DNA-DNA relatedness $(82 \%)$, demonstrating their affiliation to the same species in accordance with the cut-off value of $70 \%$ recognized by Wayne et al. (1987) for discrimination of bacterial species. Strain KMM $330^{\mathrm{T}}$ exhibited low DNA-DNA relatedness with a range of closely and more distantly related type strains of $P$. aeruginosa $(7 \%)$, P. fluorescens (6\%), P. fulva (6\%), P. luteola (3\%), P. parafulva (7\%), P. putida (8\%), P. straminea (9\%) and P. stutzeri $(9 \%)$. Based on the $16 \mathrm{~S}$ rRNA gene sequence similarity values $(<97 \%)$, their placement in the phylogenetic tree (Fig. 1) and levels of DNA-DNA relatedness, isolates KMM $330^{\mathrm{T}}$ and KMM 331 should be classified as a novel species within the genus Pseudomonas.

The phylogenetic distinctiveness found for strains KMM $330^{\mathrm{T}}$ and KMM 331 was supported by a combination of phenotypic features that does not allow their assignment to any recognized species of the genus Pseudomonas. The new marine isolates displayed a number of phenotypic characteristics that differentiate them from representatives of each of their related phylogenetic groups, including 'fluorescent', non-pigmented denitrifying or intracellularpigmented Pseudomonas species. The phylogenetic relatives $P$. fulva, $P$. parafulva and P. luteola could be distinguished from strains KMM $330^{\mathrm{T}}$ and KMM 331 based on the presence of intracellular pigments and utilization of various compounds. Strains KMM $330^{\mathrm{T}}$ and KMM 331 were consistent with $P$. alcaligenes in their lack of carbohydrate utilization, but they differed in their inability to denitrify or to produce arginine dihydrolase and in their ability to grow in $8-10 \% \mathrm{NaCl}$. In addition, the DNA G $+\mathrm{C}$ content of strains $\mathrm{KMM} 330^{\mathrm{T}}$ and KMM $331(61 \cdot 1-61 \cdot 5 \mathrm{~mol} \%)$ clearly distinguished them from $P$. alcaligenes (64$68 \mathrm{~mol} \%$ ) (Palleroni, 1984). Differential physiological and biochemical characteristics of the new marine isolates and a range of Pseudomonas species are summarized in Table 1. The most significant differential characteristics for strains KMM $330^{\mathrm{T}}$ and KMM 331 are the inability to produce pigments, to denitrify, to produce arginine dihydrolase and to grow at $4{ }^{\circ} \mathrm{C}$ and the ability to grow in the presence of $8-10 \% \mathrm{NaCl}$.

On the basis of combined phenotypic and phylogenetic data, the marine sponge isolates KMM $330^{\mathrm{T}}$ and KMM 331 are considered to represent a novel species, for which the name Pseudomonas pachastrellae sp. nov. is proposed.

\section{Description of Pseudomonas pachastrellae sp. nov.}

Pseudomonas pachastrellae (pa.cha.strel'lae. N.L. gen. n. pachastrellae of Pachastrella, the generic name of a sponge).

Gram-negative, aerobic, non-pigmented, encapsulated, 
rod-shaped cells, $1 \cdot 4-1 \cdot 6 \mu \mathrm{m}$ long and $0 \cdot 4-0.5 \mu \mathrm{m}$ in diameter, that are motile by a single flagellum. Oxidase- and catalase-positive. Forms circular, smooth, non-pigmented, whitish and transparent colonies, $2-3 \mathrm{~mm}$ in diameter, on TSA and MA. Pyocyanin on King A medium and fluorescent pigments on King B medium are not produced. A slightly yellowish diffusible pigment is observed during growth of strain KMM $330^{\mathrm{T}}$ on King A medium. Growth is observed in $0-10 \%(\mathrm{w} / \mathrm{v}) \mathrm{NaCl}$ and at temperatures of $7-41{ }^{\circ} \mathrm{C}$; no growth occurs at 4 or $42^{\circ} \mathrm{C}$. Acid is not produced from D-glucose, D-xylose, rhamnose, galactose, maltose, lactose or mannitol. Variable production of acid from glycerol. Hydrolysis of Tween 40 is positive. In addition to the physiological characteristics given in Table 1, the strains are negative for urease, lysine decarboxylase, ornithine decarboxylase, acetoin production, $\mathrm{H}_{2} \mathrm{~S}$ production, indole production, aesculin and DNA hydrolysis, haemolysis and utilization of L-arabinose, phenylacetate, DL-norleucine and $\mathrm{N}$-acetylglucosamine and positive for citrate and DLlactate utilization. In APY ZYM tests, strains are positive for esterase C4, esterase lipase C8, phosphoamidase, leucine arylamidase reaction and negative for alkaline phosphatase, lipase C14, valine arylamidase, cystine arylamidase, $\alpha$-chymotrypsin, trypsin, acid phosphatase, $\alpha$-galactosidase, $\beta$-galactosidase, $\beta$-glucuronidase, $\alpha$ glucosidase, $\beta$-glucosidase, $N$-acetyl- $\beta$-glucosaminidase, $\alpha$-mannosidase and $\alpha$-fucosidase. The major isoprenoid quinone is $\mathrm{Q}_{9}$. The phospholipids are PE, PG, DPG and an unknown phospholipid. Strains KMM $330^{\mathrm{T}}$ and KMM 331 contain $\mathrm{C}_{16: 0}$ (20 and $17 \cdot 6 \%$, respectively), $\mathrm{C}_{16: 1} \omega 9 c$ $(23.5$ and $23.0 \%)$ and $\mathrm{C}_{18: 1}(41.7$ and $44.9 \%)$ as major fatty acids, as well as $\mathrm{C}_{12: 0}(6 \cdot 9$ and $4 \cdot 9 \%) . \mathrm{C}_{12: 1}$, iso- $\mathrm{C}_{13: 0}$, $\mathrm{C}_{13: 0}, \mathrm{C}_{13: 1}, \mathrm{C}_{14: 0}, \mathrm{C}_{14: 1} \omega 7 c, \mathrm{C}_{14: 0} 3-\mathrm{OH}, \mathrm{C}_{15: 0}$, iso- $\mathrm{C}_{15: 0}$, iso- $\mathrm{C}_{16: 0}$, iso- $\mathrm{C}_{17: 0}, \mathrm{C}_{12: 0} 3-\mathrm{OH}, \mathrm{C}_{17: 1} \omega 8 c, \mathrm{C}_{17: 0}, \mathrm{cyc}-\mathrm{C}_{17: 0}$ and $\mathrm{C}_{18: 0}$ are present at $\leqslant 1 \%$. The $\mathrm{G}+\mathrm{C}$ content of the DNA is $61 \cdot 1-61.5 \mathrm{~mol} \%$ (determined by the thermal denaturation method).

The type strain, KMM $330^{\mathrm{T}}\left(=\mathrm{JCM} 12285^{\mathrm{T}}=\mathrm{NRIC}\right.$ $0583^{\mathrm{T}}=$ CCUG $46540^{\mathrm{T}}$ ), was isolated from the sponge Pachastrella sp., collected from the Philippine Sea at a water depth of $750 \mathrm{~m}$.

\section{Acknowledgements}

We would like to thank Dr Chantal Bizet, Collection de l'Institut Pasteur, Paris, for the gift of Pseudomonas strains and Miss Tomoko Kawakami for her technical assistance. This study was supported by grant no. 05-04-48211 from the Russian Foundation for Basic Research, grant no. 2-2.16 from the Federal Agency for Science and Innovations of the Ministry for Education and Science of the Russian Federation, and by grants from the Presidium of the Russian Academy of Sciences 'Molecular and Cell Biology'.

\section{References}

Anzai, Y., Kudo, Y. \& Oyaizu, H. (1997). The phylogeny of the genera Chryseomonas, Flavimonas, and Pseudomonas supports synonymy of these three genera. Int J Syst Bacteriol 47, 249-251.
Anzai, Y., Kim, H., Park, J.-Y., Wakabayashi, H. \& Oyaizu, H. (2000). Phylogenetic affiliation of the pseudomonads based on 16S rRNA sequence. Int J Syst Evol Microbiol 50, 1563-1589.

Baumann, P., Bouditch, R. D., Baumann, L. \& Beaman, B. (1983). Taxonomy of marine Pseudomonas species: P. stanieri sp. nov.; $P$. perfectomarina sp. nov., nom. rev.; P. nautica; and P. doudoroffii. Int J Syst Bacteriol 33, 857-865.

Bennasar, A., Rosselló-Mora, R., Lalucat, J. \& Moore, E. R. B. (1996). 16S rDNA sequence analysis relative to genomovars of Pseudomonas stutzeri and proposal of Pseudomonas balearica sp. nov. Int J Syst Bacteriol 49, 200-205.

Brown, G. R., Sutcliffe, I. C. \& Cummings, S. P. (2001). Reclassification of [Pseudomonas] doudoroffii (Baumann et al., 1983) into the genus Oceanomonas gen. nov. as Oceanomonas doudoroffii comb. nov., and description of a phenol-degrading bacterium from estuarine water as Oceanomonas baumannii sp. nov. Int J Syst Evol Microbiol 51, 67-72.

De Ley, J., Cattoir, H. \& Reynaerts, A. (1970). The quantitative measurement of DNA hybridization from renaturation rates. Eur J Biochem 12, 133-142.

Ezaki, T., Hashimoto, Y. \& Yabuuchi, E. (1989). Fluorometric deoxyribonucleic acid-deoxyribonucleic acid hybridization in microdilution wells as an alternative to membrane filter hybridization in which radioisotopes are used to determine genetic relatedness among bacterial strains. Int J Syst Bacteriol 39, 224-229.

Hall, T. A. (1999). BIOEDIT: a user-friendly biological sequence alignment editor and analysis program for Windows 95/98/NT. Nucleic Acids Symp Ser 41, 95-98.

Hauser, E., Kämpfer, P. \& Busse, H.-J. (2004). Pseudomonas psychrotolerans sp. nov. Int J Syst Evol Microbiol 54, 1633-1637.

Jukes, T. H. \& Cantor, C. R. (1969). Evolution of protein molecules. In Mammalian Protein Metabolism, pp. 21-132. Edited by H. N. Munro. New York: Academic Press.

Kersters, K., Ludwig, W., Vancanneyt, M., De Vos, P., Gillis, M. \& Schleifer, K.-H. (1996). Recent changes in the classification of pseudomonads: an overview. Syst Appl Microbiol 19, 465-477.

King, E. O., Ward, M. K. \& Rainey, D. E. (1954). Two simple media for demonstration of pyocyanin and fluorescein. J Lab Clin Med 44, 301-307.

Leifson, E. (1963). Determination of carbohydrate metabolism of marine bacteria. J Bacteriol 85, 1183-1184.

Marmur, J. (1961). A procedure for the isolation of deoxyribonucleic acid from microorganisms. J Mol Biol 3, 208-218.

Marmur, J. \& Doty, P. (1962). Determination of the base composition of deoxyribonucleic acid from its thermal denaturation temperature. J Mol Biol 5, 109-118.

Moore, E. R. B., Mau, M., Arnscheidt, A., Böttger, E. C., Hutson, R. A., Collins, M. D., van de Peer, Y., de Wachter, R. \& Timmis, K. T. (1996). The determination and comparison of the $16 \mathrm{~S}$ rDNA gene sequence of species of the genus Pseudomonas (sensu stricto) and estimation of the natural generic relationships. Syst Appl Microbiol 19, 478-492.

Owen, J., Hill, L. R. \& Lapage, S. P. (1969). Determination of DNA base composition from melting profiles in dilute buffers. Biopolymers 7, 503-516.

Oyaizu, H. \& Komagata, K. (1983). Grouping of Pseudomonas species on the basis of cellular fatty acid composition and the quinone system with special reference to the existence of 3-hydroxy fatty acids. J Gen Appl Microbiol 29, 17-40.

Palleroni, N. J. (1984). Genus I. Pseudomonas Migula 1984, 237 ${ }^{\mathrm{AL}}$. In Bergey's Manual of Systematic Bacteriology, vol. 1, pp. 141-199. Edited by N. R. Krieg \& J. G. Holt. Baltimore: Williams \& Wilkins. 
Pearson, W. \& Lipman, D. J. (1988). Improved tools for biological sequence comparison. Proc Natl Acad Sci U S A 85, 2444-2448.

Peix, A., Rivas, R., Mateos, P. F., Martínez-Molina, E., RodríguezBarrueco, C. \& Velásquez, E. (2003). Pseudomonas rhizosphaerae sp. nov., a novel species that actively solubilizes phosphate in vitro. Int J Syst Evol Microbiol 53, 2067-2072.

Rainey, P. B., Thompson, I. P. \& Palleroni, N. J. (1994). Genome and fatty acid analysis of Pseudomonas stutzeri. Int J Syst Bacteriol 44, 54-61.

Rosselló, R. A., García-Valdés, E., Lalucat, J. \& Ursing, J. (1991). Genotypic and phenotypic diversity of Pseudomonas stutzeri. Syst Appl Microbiol 14, 150-157.

Rosselló-Mora, R. A., García-Valdés, E. \& Lalucat, J. (1993). Taxonomic relationship between Pseudomonas perfectomarina ZoBell and Pseudomonas stutzeri. Int J Syst Bacteriol 43, 852-854.

Saitou, N. \& Nei, M. (1987). The neighbor-joining method: a new method for reconstructing phylogenetic trees. Mol Biol Evol 4, 406-425.

Shida, O., Takagi, H., Kadowaki, K., Nakamura, L. K. \& Komagata, K. (1997). Transfer of Bacillus alginolyticus, Bacillus chondroitinus, Bacillus curdlanolyticus, Bacillus glucanolyticus, Bacillus kobensis, and Bacillus thiaminolyticus to the genus Paenibacillus and emended description of the genus Paenibacillus. Int J Syst Bacteriol 47, 289-298.

Smibert, R. M. \& Krieg, N. R. (1994). Phenotypic characterization. In Methods for General and Molecular Bacteriology, pp. 607-655. Edited by P. Gerhardt, R. G. E. Murray, W. A. Wood \& N. R. Krieg. Washington, DC: American Society for Microbiology.

Stackebrandt, E. \& Goebel, B. M. (1994). Taxonomic note: a place for DNA-DNA reassociation and 16S rRNA sequence analysis in the present species definition in bacteriology. Int J Syst Bacteriol 44, 846-849.
Svetashev, V. I., Vysotskii, M. V., Ivanova, E. P. \& Mikhailov, V. V. (1995). Cellular fatty acids of Alteromonas species. Syst Appl Microbiol 18, 37-43.

Thompson, J. D., Gibson, T. J., Plewniak, F., Jeanmougin, F. \& Higgins, D. G. (1997). The CLUSTAL_X windows interface: flexible strategies for multiple sequence alignment aided by quality analysis tools. Nucleic Acids Res 25, 4876-4882.

Uchino, M., Kosako, Y., Uchimura, T. \& Komagata, K. (2000). Emendation of Pseudomonas straminea lizuka and Komagata 1963. Int J Syst Evol Microbiol 50, 1513-1519.

Uchino, M., Shida, O., Uchimura, T. \& Komagata, K. (2001). Recharacterization of Pseudomonas fulva Iizuka and Komagata 1963, and proposals of Pseudomonas parafulva sp. nov. and Pseudomonas cremoricolorata sp. nov. J Gen Appl Microbiol 46, 247-261.

Vaskovsky, V. E. \& Terekhova, T. A. (1979). HPTLC of phospholipid mixtures containing phosphatidylglycerol. J High Resolut Chromatogr 2, 671-672.

Wayne, L. G., Brenner, D. J., Colwell, R. R. \& 9 other authors (1987). Report of the ad hoc committee on reconciliation of approaches to bacterial systematics. Int J Syst Bacteriol 37, 463-464. Wilkinson, S. G. (1988). Gram-negative bacteria. In Microbial Lipids, vol. I, pp. 299-488. Edited by C. Ratledge \& S. G. Wilkinson. London: Academic Press.

Yoon, J. H., Kim, H., Kang, K. H., Oh, T. K. \& Park, Y. H. (2003). Transfer of Pseudomonas elongata Humm 1946 to the genus Microbulbifer as Microbulbifer elongatus comb. nov. Int J Syst Evol Microbiol 53, 1357-1361.

Yumoto, I., Yamazaki, K., Hishinuma, M., Nodasaka, Y., Suemori, A., Nakajima, K., Inoue, N. \& Kawasaki, K. (2001). Pseudomonas alcaliphila sp. nov., a novel facultatively psychrophilic alkaliphile isolated from seawater. Int J Syst Evol Microbiol 51, 349-355. 